Anna Wyrwisz

Jagiellonian University, Kraków anna.wyrwisz@uj.edu.pl

(D) https:/ / orcid.org/ 0000-0003-3698-5932

\title{
The United States of America and the End of Dutch Colonial Rule in Indonesia
}

\begin{abstract}
The United States had developed trade relations with the Dutch East Indies before World War I. In the 1920s, American diplomatic services prepared reports on the economic and political situation in the Dutch colony. The U.S. wanted to defend their interests in the region. In 1949, after several years of attempts to regain power in Indonesia, the Dutch withdrew in the absence of American support. A decade later, suchlike events occurred in connection with Dutch New Guinea.
\end{abstract}

Key words: U.S. foreign policy; Dutch East Indies; decolonization

The aim of the paper is to analyze the nature of U.S. politics toward the Dutch East Indies. The thesis of this paper is that the Dutch East Indies became an important part of the foreign policy and security of the United States shortly before it gained independence and international recognition as Indonesia. The analysis implies reflection on Dutch-American relations. The Netherlands ruled Indonesia, but American influence and the U.S. role in decolonization is the biggest sore spot in the long history of close Dutch-American relations. Because of the connections among the United States, the Netherlands and Indonesia, the situation in New Guinea in the period following the existence of the Dutch East Indies is discussed here as well.

The text covers the period from the eighteenth century to the 1960s. Content analysis is used as the research method (Marsh, and Stoker 236-40). The subject of the research is provided by primary and secondary sources. The works on American foreign policy are too numerous to count. However, there is a lack of publications in the Polish literature on the U.S. and the formation of the Republic of Indonesia. The theoretical perspective of structural realism can be used to explain the policy of the United States toward the Dutch East Indies. Structural realism explains international relations by referring to the unequal capacities of states and the anarchic structure of the system of states (Jackson, and Sørensen 77-81). 
I will deal with the subject in five parts. In the first section the article focuses on the United States and the establishment of economic contacts with Dutch East Indies in the nineteenth century. Then the article focuses on the period of the World Wars, and follows with a description of the impact of U.S. policy on the loss of the Dutch East Indies and Dutch New Guinea. In 1949, after a few years of trying to restore its power over Indonesia, which was fighting for its independence, the Dutch withdrew without American support. After a decade, the Dutch territory of New Guinea was the key to Indonesia for the Kennedy administration. After ineffective diplomatic moves from The Hague, and with American pressure, the colony came under control of the United Nations and then became a part of Indonesia.

\section{The Dutch East Indies and their relations with the United States in $18^{\text {th }}$ and $19^{\text {th }}$ centuries}

In this section I start with a general overview of Dutch colonial policy and then move on to the issue of U.S.-Dutch East Indies relations until World War I. The Dutch Golden Age (Gouden Eeuw) not only gave the world masterpieces of Dutch artists such as Jan Vermeer, Antoon van Dyck and Rembrandt. In the era of geographic discoveries, there was extremely valuable progress in the field of cartography among others. It is evident from looking at a world map just how much power the Republic of the United Provinces gained in the seventeenth century, and how greatly it contrasted with the size of the current territory of the Kingdom of the Netherlands. Dutch sailors, seeking new trade routes, dominated an area sixty times bigger than their own European nation. The Dutch enjoyed personal freedom, religious freedom, and prosperity, and could thus focus on conquest and trade. There was a rapid economic boom, as a result of which the Republic became one of the richest countries, as well as the maritime and commercial power of Europe (Modelski). The Dutch East India Company (Verenigde Oost-Indische Compagnie, VOC), established in 1602 and financed by the state, was for a long time the largest trader in the world (Hooker 96-97). It emerged from small companies and was the first international trader in the world. It had a monopoly on colonial activity in Asia. On the island of Java, it founded the city of Batavia (today's Jakarta), which became the centre of trade operations in the Far East. At the peak of its power, VOC had commercial ports in Persia, India, China, Japan and the East Indies.

The fall of the Republic of the United Provinces was a result of a longer process. For the Dutch, trade with the Far East always seemed to be of utmost importance. However, at the turn of the century, the Dutch East India Company was finally dissolved in 1799. The position of the Netherlands on the seas had become much curtailed. England, once again at war with the Netherlands, continued to paralyze its trade and take over Dutch colonies. The Netherlands maintained its dominance in Indonesia, but lost its colonies in India, Ceylon (1780), Cape Town, and the Spice Islands (1801) (Rochon 249). The Netherlands maintained the Dutch East Indies, several properties in the Gulf of the Guinea, the islands of Aruba, Bonaire, Curaçao, Saba, Sint Eustatius and the southern part of Sint Maarten in the Caribbean, and Suriname. In terms of territory, the Netherlands was still one of the colonial empires 
of the nineteenth century. Politically, it became less and less important. The period of the formation of the United States of America meant for the Netherlands the irreversible end of being one of the world's superpowers.

The Dutch East Indies was a Dutch colony from 1799. Previously, the colonial system had been managed by the VOC. Conquering the territories that constitute today's Indonesia ended at the beginning of the 20th century. It was not a settlement colony. From the very beginning, its activity was focused on profit. The Indonesian islands were rich in spices, such as pepper, cloves, nutmeg, and sandalwood, and India rubber, tea, coffee, natural gas, and crude oil.

The United States in the mid-nineteenth century was, despite the Monroe Doctrine, becoming rich and developing, not limited only to commercial and economic contacts in its own hemisphere. The example of American-Dutch cooperation in Japan in the middle of the nineteenth century appears to be ignored by American historians. Meanwhile, the Dutch worked hard to maintain the best possible contacts with closed Japan, and in time they acted as an intermediary in dealing with the first American expeditions of Matthew Perry in 1853 and 1854. The Dutch undoubtedly contributed to the success of these expeditions in terms of the process of the gradual opening of Japan. Before the Americans appeared in Japan, the Dutch had managed to maintain trade ties with Japan for over two centuries (Chaiklin).

The trade between the Dutch East Indies and the United States was dynamically developing. Exports from present-day Indonesia to the United States exceeded imports. It increased from 0.9 million guilders in 1870 to 28 million guilders at the turn of the nineteenth and twentieth centuries, accounting for over ten percent of Indonesia's exports. This mainly concerned coffee and sugar, but also other agricultural products and tin (Touwen 274-76).

At the beginning of the twentieth century, the United States was the third-largest importer to the Netherlands. Exports from the Netherlands to the United States were three times smaller, but the value of exports to the United States from the Dutch East Indies was estimated at around 10\% of their total exports (Touwen 279). In this period the Dutch colony was an important trade source for American growth.

\section{American policy and political changes in the region in the period of interbellum}

In this section I focus on Dutch East Indies and their relations with the United States in the 1920s and 1930s. During World War I it was not possible for the Netherlands to trade with the Dutch East Indies. The latter developed at that time and after the war maintained broader trade relations with the United States, Australia and Japan.

During World War I, Japan took over German colonies. The United States, unwilling to recognize Japanese expansion, convened the international Washington Conference that lasted from November 12, 1921 to February 6, 1922, and resulted in the conclusion of a number of treaties. The Conference concerned the regulation of international relations in the Far East, naval armaments and the limit of the tonnage of heavy warships, and the recognition of China's sovereignty. The Netherlands 
took limited participation in the conference as a colonizer of the East Indies and became one of the signatories of the treaty on respect and joint defense of the territorial status quo in the Pacific Ocean to secure its rich colonies and develop trade in the Far East, despite adhering to the principles of neutrality in that period (Balicki, and Bogucka 383). Also, the U.S. initiative associated with the Washington Conference did not fit into the alleged American isolationism at that time. However, the distance toward the League of Nations should not indicate inactivity in international affairs or the Conference's initiative directly related to American interests. The Conference and its final agreements became something that could have replaced the League of Nations from the perspective of American diplomacy, and at the same time created security for the future without hampering the freedom of U.S. activity throughout the world. The U.S. Secretary of State Charles Evans Hughes had not expected himself to succeed in persuading Britain and Japan to significant arms reductions. Much more surprising than the American proposals was the fact that the Conference participants finally agreed to accept most of its conclusions. Importantly, the Washington Conference began a new era of efforts to protect peace, which for many is synonymous with the protection of international economic interests of the United States, without accepting active international responsibilities (Brinkley 729-30). Participation in the Conference was also to uphold the symbolism of the prestige of the Netherlands as a colonial power in the perception of the growing national selfawareness of the Indonesians. After a decade, the Washington Conference broke down when the Japanese announced the independence of Manchuria.

In general after World War I, despite the popularity of isolationism among many American politicians, the growing power of the United States became more and more involved in the international arena, especially when it concerned national interests. The political power of the Netherlands was becoming less and less significant. The Hague focused on adhering to the neutrality and the submission of the interests in peace processes that would guarantee the status quo. Nothing, however, could negatively affect the intensifying economic relations between the United States and the Netherlands.

In the 1920s the American diplomatic service created reports on economic and political issues in the Dutch East Indies for the U.S. State Department. Americans wanted to defend their own interests in the region - so rich in oil, rubber, tin and tobacco. In 1920, Americans drafted a report on concessions and the rights associated with the extraction of oil in the Dutch East Indies. A need to create facilities for U.S. efforts in obtaining oil extraction concessions in other countries was claimed. Japan also made claims for equal opportunities in investing capital in the Dutch East Indies (Vandenbosch 202-205). The Dutch did not firmly block foreign capital from investing in its colony, rich in deposits, fearing that it might become a source of international conflict.

The international political aspirations of the United States grew as well. The first reports expressed appreciation for the wise and efficient management of the Dutch colony (Gouda, and Zaalberg 66-67). American experiences with the Philippines and examples from Western European countries and their overseas territories also played a role in how the U.S. perceived other countries in the interwar period. It was connected with increasing awareness and reflections on European countries, enriching themselves at the expense of colonies. 
In the 1930s the American position toward the Dutch East Indies can be characterized twofold, as also the U.S. foreign policy can be characterized as realism concerning American vital interests on the one hand and Wilsonian idealism on the other. Over the decade the tone of the reports took on an increasingly critical form, particularly with regard to Dutch suppression the emerging Indonesian nationalism, freedom of the press, and civil liberties (Gouda, and Zaalberg 66-67).

Franklin Delano Roosevelt's presidency in the United States meant criticism of the Dutch governments in East Indies. The idea of granting independence to the only American colony, the Philippines, and eliminating colonialism throughout the world rose in the United States. This was contrasted with the despotic rule of Governor Bonifacius Cornelis de Jonge in the Dutch colony and the economic exploitation of the colonies by the Netherlands. At the same time, the Americans were fearful of turning the East Indies toward Japan and its growing ambitions. In addition, the establishment of customs barriers in the colony, which the United States disapproved of, exacerbated the situation (Gouda 520-30).

Even so, in the 1930s the Americans continued to exchange goods with the Dutch East Indies, which became more important to them than trade with the Netherlands. American capital also took part in the exploitation of bauxite deposits in Suriname. American investments in colonial Indonesia accounted for $7 \%$ of all foreign investment in the Dutch East Indies, and on the eve of World War II, after the Great Depression, which also affected the colony, the United States procured, in addition to other valuable goods, $48.7 \%$ (Gouda 524) of Indonesian rubber. It was used, among other things, in the galloping development of the automotive industry in Detroit. Indonesian exports to the United States also included tin $(8 \%$ of the total Indonesian exports), quinine, palm oil, coffee, and tea.

\section{Southeast Asia during World War II}

In this section I concentrate on the period of World War II. Dutch policy in the colony came under more and more criticism from the United States, which encouraged granting independence to Indonesia, with the Philippines serving as an example. Yet, at that time it could be only a political suggestion or one of numerous options. From the economic perspective the islands were an important source of rubber, sugar, and coffee. From the political perspective, the United States was afraid the unhappy nation would turn for help to the Japanese, who would most probably be eager to exploit the situation for their own purposes. The Netherlands, however, would not listen when it came to rapid decolonization. With the outbreak of World War II, the U.S. attitude towards the Dutch East Indies colonialism again took a different direction. Most important from the perspective of the United States was to have an ally in this part of the world while not, however, denying the emerging Indonesian national identity (Gouda, and Zaalberg 66-67).

President Franklin Roosevelt thought that colonialism was creating international tensions in the interwar period and believed that the war actions of Allies against the Nazis and totalitarian countries should result in global freedom and independence. He likewise supposed that a world order without colonialism would minimalize tensions and conflicts. The Dutch government in exile in London was aware of the 
American point of view, but no steps regarding reforms in its imperium were made (Frey 609-20).

The Netherlands, occupied by the Reich, was unable to defend its colonial possessions, and the Dutch were hoping that the Americans would defend the East Indies. After the Japanese attack on Pearl Harbor in 1941, the United States entered the war and on the $8^{\text {th }}$ December the Netherlands declared war against Japan as well. The American-British-Dutch-Australian Command (ABDA) initiative was created. The Netherlands, like the United Kingdom, fought to protect its colonies. There were misunderstandings among the military leaders regarding the appropriate tactics and war strategy in the region. The Netherlands was not a military power in the war against the Axis. Although with its overseas colonies it wanted to be perceived as a mid-sized power, its voice in warfare decisions and the first outlines of postwar order was, from its point of view, marginalized. However, it was impossible to disagree with this state of affairs.

World War II and its consequences irreversibly changed the international order of the world. European countries were forced to bitterly accept the fact that they had lost their previous positions and roles. At first everyone appeared to be completely aware of the importance of American help. The beginning of the anti-American moods in the Dutch navy was caused by Dutch humiliation and diminishment stemming from General Douglas MacArthur ignoring the strategic capabilities of the Dutch East Indies bases (Teitler 72-73). As one of the Dutch researchers put it (Teitler 72) - one of the last places where anti-Americanism in the Netherlands should be sought was in the armed forces. It was difficult for the Dutch navy to accept the decision of MacArthur to avoid the Dutch East Indies while the U.S. troops were headed for the Philippines against Japan. It was believed that he had ignored the strategic possibilities, despite being offered a first-class naval base. There was also an opinion about his alleged 'flirting' with the Dutch navy due to the need for its ships (Teitler 79). The main aim for the America during the war was indeed to win it. After the war, the Kingdom of the Netherlands was still one of the largest colonial powers in the world. The Dutch navy could participate in maintaining international stability, at least from the Dutch point of view. Naval commanders stressed the importance of naval supremacy over land forces. They were irritated that in the United States it was not assumed the Dutch would be able to fight the revolution and the uprising in the East Indies themselves. In addition, evidence of American perfidy was cited, claiming that the United States wanted the Netherlands to be strong in Europe but not on the Asian scene. It was obvious, as some assumed, that the Americans were afraid of Dutch competition in the attractive East Asian market. The Dutch had many years of experience there and the Americans in fact asked the Dutch to give up this advantage (Teitler 79).

ABDA was short-lived anyway, as differences between the four nations led to difficulties in coordinating actions. The Allied fleet could not stop Japan, which after the attacks on Pearl Harbor and the Philippines in December 1941 was headed toward the Dutch East Indies. Unstoppable Japan took control over the whole colony in March 1942. During more than three years of ongoing Japanese occupation, Indonesian feelings of independence were gaining in strength. The purpose, from the Japanese perspective, was to facilitate the supply of oil, backed by institutions and 
leaders like the nationalistic Sukarno. The Japanese announced they would grant Indonesia independence and the symbols of Dutch administration were destroyed (Frey 612-14).

After three years of Japanese wartime occupation, Sukarno declared himself president and announced independence on $17^{\text {th }}$ August 1945, two days after the Japanese capitulation. The Dutch sought to restore their power. They had to face their own principles about the recognition and obedience of the international rule of law. The Dutch, however, wanted this matter to be recognized as a domestic issue.

In 1945 Sukarno and Vice-president Mohammad Hatt were accused by the Dutch of collaborating with the Japanese, and after receiving military support from the United States, the administration of the Dutch East Indies gradually began to take over lands from the British, whose task was to disarm the remaining Japanese, and rebuild governments on the islands.

The Dutch army engaged in conflict with Indonesia fighting for its independence. From today's perspective, or at least from the standpoint of years that followed decolonization of the Dutch overseas possessions, there is a belief that even in the interwar period only individuals highly resistant to the signals coming from the colonies might not want to notice the impending end of the supremacy of the Dutch in Indonesia.

In the military environment, the Dutch navy again felt strange pressure to concentrate on continental matters in order to leave the rest to the Americans. In addition, from the political point of view, the Dutch no longer had the option to remain outside the nascent North Atlantic Alliance, although the policy of neutrality was officially observed until World War II. Even the Dutch government itself did not want to expand the naval forces and wanted to place its ships at the disposal of the Alliance. Despite opposition to these proposals, the government joined NATO and the separate naval department was dissolved. The Netherlands also lost the East Indies. The naval forces lost their importance in order to build a strong army and air force. And of course, the Americans were blamed for that (Teitler 79). The end of World War II indeed marked a new phase in world politics, with the United States not only reacting to but also creating international affairs.

Politically, the growing international political aspirations of the United States began to materialize as a result of the outbreak of war. Allied decisions, including America as the leader, were made above the heads of the Dutch. At the same time, Dutch positive feelings towards Americans in general rose as they, among others, liberated the nation in 1945 after several years of occupation. This date is considered as the beginning of new phase in international relations, and the beginnings of a bipolar world. According to a simple ideological division, the United States and the Netherlands belonged to the part of the world that stood in opposition to communism. It was another new factor connecting the two countries. They became members and cooperated in the framework of the most important international organizations, and it should be recognized here that in the Netherlands American dominance was expected, rather than the dominance of one of their European neighbors. In 1953 the American Committee for Cultural Freedom named the Netherlands the most pro-American country in Europe (Roholl 147). 


\section{Indonesia}

In this section I focus on the years from 1945 to 1949. The end of World War II meant for the Netherlands the pursuit of international cooperation, in which the United States was the leader. At the same time, immediately after the war, the Netherlands decided to restore its prewar position as a colonial power by resuming its dominance over today's Indonesia. The occupation of the islands by the Japanese and the subsequent announcement of independence by the Indonesians was unacceptable for the Dutch. Neither did The Hague want to listen to anything about a rapid decolonization process.

Initially, the United States did not appear to be interested in stopping the Dutch activities in the region, and the Dutch interpreted this inaction as support. On November 1946, the Linggadjati Agreement was signed, which guaranteed a peaceful coexistence with Indonesian nationalists. After the agreement was reached, the United States turned down a request for a loan for the colony because of the communist threat in the region (Frey 611). From the American perspective, denying Indonesians the right to self-determination was not a primary issue. The United States had to take care of its interests. Among others, American Ambassador Stanley K. Hornbeck informed from The Hague about the uncertain situation in Indonesia, which could have fallen under non-Western influence. On the other hand, the economic stability of the Netherlands was also in the interests of the United States. The Netherlands depended largely on economic relations with Indonesia. The United States, however, threatened the Netherlands with cutting off supplies under the Marshall Plan. Articles appeared in the American press which emphasized the analogies between the Indonesians' aspirations for independence, democratic rights, and the American Revolution and the American Declaration of Independence of 1776. Almost 500 letters were sent to the U.S. State Department in which Americans expressed support for the Indonesians. There were also demonstrations, albeit small, condemning Dutch efforts to maintain the colonial status quo. Demonstrators in 1947 in front of the Dutch consulate in Los Angeles held a placard reading: 'Holland Loves Freedom - So Does Indonesia' (Gouda, and Zaalberg 154). Taking into account visible anti-colonial sentiments in American society, and sympathies in Congress for the cause of Indonesia, it was not easy for the U.S. government to take the side of their ally the Netherlands in this conflict (Staden 83).

By 1947, however, the Americans were officially neutral, which meant tacit agreement with the Dutch policy. The prospect of military action, however, did not diminish, although the vision of the economic recovery of Indonesia's rich natural resources was distancing. Loans granted to the Dutch East Indies could not be realized due to the precarious situation in the country. In addition, the employees of the American Central Intelligence Group (CIG) argued that the armed conflict may have been caused by anti-Western moods among Indonesians (Gouda, and Zaalberg 202). In the U.S., the foreign policy effects of George Kennan's famous Long Telegram (Kennan) started to appear. Kennan's analysis on the Soviet Union influenced the U.S. policy of containment.

Meanwhile, more and more troops were being sent to the colony. Indonesian reactions were bloody. Under the pretext of breaking the Linggadjati agreement, and to bring law and order, the first 'policy action' began on the $20^{\text {th }}$ of July 1947 
(Wesseling 123). With more and more alarming reports coming from DEI, the United States participated more actively. For the Dutch it meant interference in their domestic politics (Staden 83). Dutch 'policy action' was met with negative opinions from Great Britain, Australia, India, and the Soviet Union as well. The United States came to support the Republic of Indonesia in the United Nations. On the $4^{\text {th }}$ of $\mathrm{Au}-$ gust, the United Nations Security Council adopted a resolution calling for the end of the conflict. Washington offered to mediate. The Netherlands accepted the U.N. conditions, but The Hague was shocked by the lack of support from Washington. During Dutch-American diplomatic contacts, the Dutch side suggested that even though some Dutch politicians were considering full Indonesian independence, in general no changes were about to appear in this matter. At the same time, there were attempts to convince the United States that 'the Indonesian question would have a very substantial bearing on the financial situation of the Netherlands Government and would reflect on Holland's ability to cooperate with and assist its neighbors and its capacity to help in any plans which might result from the European Recovery Program discussions' (Memorandum).

The Renville Plan, signed on a U.S. warship in January 1948, presented American concepts of decolonization, which was at that time long-term cooperation between Indonesia and Holland (Frey 612-14). Regardless of the shape of the agreement, both sides expected something different and could reach an agreement.

Six months later American Ambassador Herman Baruch informed the U.S. Secretary of State about his conversations with new Dutch Prime Minister Willem Drees, who tried to convince Baruch that the delicately balanced economy of Indonesia can only support a population of 75 million people with Western guidance and assistance which the Netherlands is competent and willing to give to the Indonesians. He spoke calmly and with conviction of the newly-formed Cabinet's plans for the immediate future in Indonesia, and I was favorably impressed with his sincerity and determination' (Baruch).

After the second Dutch 'policy action' in December 1948, the U.S. was again among its international critics. Besides another U.N. resolution, the Netherlands was threatened with the termination of aid from the Marshall Plan. With increasing casualties, the United States called on the U.N. Security Council to demand a ceasefire. Even more pressure fell on Washington when Indonesians, led by Hatta, crushed the communist Madioen uprising. Within days many communists were killed. It was proof for the Americans that Republic of Indonesia should gain independence (Berkel, and Goei 203). First an adviser was sent to the Indonesian nationalists from the freshly established Central Intelligence Agency (Frey 613).

The Netherlands, without natural resources, used resources from overseas colonies, so it is not strange that for a long time the Dutch in general could not be easily reconciled with the loss. Colonies were needed to rebuild the country from the enormous devastation of World War II. For the Netherlands the colonies were not only a lucrative source of income: its possession of overseas territories gave it an opportunity to belong to countries of greater importance in the international arena. The fears associated with decolonization processes were therefore multidimensional. It was feared that without its colonies the Netherlands would only become a 'North Sea farm', and its foreign policy would be reduced to the 'rank of Denmark' (Pijpers 205-06). After passionate disputes, the breaking of diplomatic 
relations and the nationalization of Dutch property in Indonesia, attempts to maintain the colonies could only happen through the military. During World War II, American President Franklin. D. Roosevelt favored the maintenance of the colony by the Netherlands. The subsequent change in Washington's position was a shock to Dutch society.

The U.S. position on the matter was changing because the situation with the Soviet Union was changing. The East-West rivalry began and Indonesian conflict could fall right into its center. From the American perspective raising nationalism in Dutch colony could become a 'bulwark' against communism (Staden 83). Additionally, in the new world order, the United States had political means and instruments that could achieve its foreign policy objectives.

Under the pressure of the Dutch economic spheres, concerned about the repercussions of the conflict on their interests with Third World countries, and against the growing social resistance against short-sighted colonial politics - but primarily as a result of the fact that the United States eventually left Dutch ally in the matter - the Netherlands had to give up (Balicki, and Bogucka 412). The Dutch could only end the war and withdraw from Indonesia. In other words, in 1949, after several years of attempts to restore its power within Indonesia fighting for its independence, the Dutch were forced to retreat in the absence of U.S. support.

In 1949, the Dutch ambassador in Washington, Eelco van Kleffens, was instructed by his superiors to announce that the Netherlands, without its ties with Indonesia, had lost interest in what they saw as a doomed Atlantic alliance (Hellema 583). In the review of the Central Intelligence Agency (CIA) of 1951 regarding the Netherlands, it was found out that as a result of a combination of several factors, notably the economic and military state of the Netherlands itself, a new global balance of power and almost total global support for Indonesians, the Netherlands was not able to stop the decolonization (National Intelligence Survey 22). It was one of the most difficult moments in the history of Dutch-American relations. The next was to happen a dozen years later.

On the day of the outbreak of the Korean War, the Dutch Foreign Minister gave an unofficial statement to the press which stated that this conflict should be seen as a test of strength between the United States and the USRR (Megens 237). The United States was nonetheless supported by the Netherlands, although the Dutch military involvement in this conflict could have had a highly negative impact on relations with New Guinea and the former Asian colony. Pressure from the United States, however, was more important for the government in The Hague.

\section{(West) New Guinea}

In this section I move on to the issue of the United States and the end of Dutch colonial rule in the 1960s. The Netherlands had kept the colony of Dutch New Guinea ${ }^{1}$, whose inhabitants were promised self-determination in the future. Indonesia, however, since becoming independent in 1949, disputed with the Netherlands over the

1 The Name of Dutch New Guinea, the western part of New Guinea Island, was used by the Kingdom of the Netherlands, while Indonesia called it West Irian or Irian Barat. 
territory. During the presidency of Dwight Eisenhower, the United States remained neutral in this matter, which meant favoring the Dutch refusal to negotiate (Webster 99). Again, as it had happened with the Indonesian way of gaining independence, American neutrality was interpreted as preferring the side of the European ally. The Netherlands, however, expected even more visible American support.

During a visit to Jakarta in February 1960, Nikita Khrushchev announced an increase in aid for Indonesia by a quarter of a million dollars. Soviet-Indonesian friendship was confirmed, and the first Indonesian president Sukarno emphasized Soviet support on the issue of West Irian. As reported by the American press - Sukarno asked during the visit: 'Doesn't the Soviet Union give the sympathy to us in the struggle for Irian Barat? (...) On the other hand, there are persons and nations who criticize us because we are friendly with the Soviet Union. I ask them, do you give assistance in the struggle against colonialism and our struggle for Irian Barat? No. They oppose us' (Kalb).

Since 1960 Indonesia had possessed fighter jets and transport planes from the United States and the Soviet Union. In that year, the Dutch sent armed forces to Asia, among which was an aircraft carrier not to be used for other purposes than as part of NATO operations. The Dutch diplomats also tried to prevent President Eisenhower from planning a visit to Jakarta, but it only generated American irritation.

In an address before the U.N. assembly on September $30^{\text {th }}, 1960$, Sukarno called upon world opinion for his agenda. He was accusing the Netherlands of imperialism, which endangered the Indonesian position: 'the situation in one the one-fifth of our national territory which still labors under imperialism'. Sukarno also suggested moving the seat of the United Nations to Africa, Asia, or Geneva as 'the United States is the protagonist of the Cold War' (Excerpts from Sukarno's Address).

After two unsuccessful attempts to gain support from the U.N. General Assembly, in 1961 Sukarno threatened to use armed force to take over the Dutch part of the island. The United States, led by the new dynamic leader John. F. Kennedy, and spurred by the possibility of the Soviet Union exploiting the crisis, again supported the Indonesians. Kennedy's presidency was characterized by the ideology of strong support for the economic growth of developing countries, which was the basis for forming stable, non-communist states. By 1962, Indonesia was the largest non-communist recipient of Soviet military aid, and military spending accounted for more than half of the Indonesian budget. For Kennedy, therefore, the issue of West New Guinea was the 'key' to Indonesia (Webster 108). The U.S. oil companies that dominated the Indonesian market also expected to end a long-standing dispute. These were, among others, the American branches of Shell, Caltex and Stanvac. John D. Rockefeller III, who controlled Stanvac, after his visit in Indonesia shared his reflections on Indonesian situation with U.S. Secretary of State Dean Rusk 'as a standoff between the pro-American army and the Communist party' (Webster 113). There were also there were American mining companies in West New Guinea uncertain over the governor of the territory. In January 1962 there was a clash between Indonesian and Dutch ships. The U.S. Attorney General and president's brother Robert Kennedy visited Jakarta and The Hague, and said in the latter that the Netherlands would not receive American support. Unofficial conversations took place in March 1962 near Washington. The representative of the Kingdom of the Netherlands, Jan Herman van Roijen, tried to enforce a plan of transferring Western New Guinea 
under the auspices of the United Nations, after which an act of self-determination would take place before it could be taken over by Indonesia. Kennedy convinced Dutch Prime Minister Jan de Quay about the superiority of Western strategic interests over Papuan self-determination with the words: 'This would be a war in which neither The Netherlands nor the West could win in any real sense. Whatever the outcome of particular military encounters, the entire free world position in Asia would be seriously damaged. Only the communists would benefit from such a conflict' (qtd. in Webster 119). American obligations in Vietnam should be kept in mind. The Dutch tried unsuccessfully to compare it to the situation to West Berlin, but in the popular opinion the population of New Guinea was perceived as not being able to bear any independence and at a different stage of development. Two years later, after fruitless Dutch diplomatic procedures and pressure from the United States, the Accord of Washington was signed and the colony first went under the U.N. administration, which was the only symbolic success of Dutch diplomacy, and afterwards became part of Indonesia. The aspirations of achieving independence of the indigenous people of this territory, which was pursued throughout the entire process and completely ignored by the American side, had not been implemented (Simpson 471).

As was the case at the end of the 1940s, the Netherlands sent troops to Southeast Asia, the situation was on the verge of war, and again Washington's decision was crucial. When Dutch politicians finally became aware of the lack of American support, they retreated (Wesseling 129). Naturally, The Hague was aware of the 'domino effect', the concern being that the fall of one state to communism would lead to the same fall in neighboring states. Nevertheless, as a close and democratic ally of America, the Dutch expected that the U.S. support would be directed to them, not to a semi-communist and demagogic Indonesian dictatorship (Wesseling 129). Selfdetermination of West New Guinea was sacrificed for American cold war strategy.

Again, for a large part of Dutch society it was not easy to accept these events, at least initially. In 1963, the Minister of Foreign Affairs of the Netherlands, Joseph Luns, rejected President Kennedy's request for a military contribution in Vietnam. Luns said: 'Do you think that, after we have, under great pressure, withdrawn 12,000 men, 16 warships, and our fighter planes - and afterwards our entire administration - from the Far East, that I could appear before the Dutch parliament with the notification: we have decided to send a battalion of marines to support the Americans in Vietnam?' (qtd. in Hellema 588). Luns publicly criticized the United States for 'its failure to support an ally in a just cause' (Luns). In 1967, in American diplomatic correspondence from The Hague to Washington, a publication that appeared in the Netherlands at that time was discussed. It was a book about Luns and his views. Luns supposedly indicated that President Kennedy was under too much influence from his brother Robert. Otherwise, his policy towards the Netherlands would be better. Robert Kennedy, according to the Dutch politician, during a few-day visit to Indonesia during the conflict, believed Sukarno that the transfer of New Guinea to Indonesia would make it an immediate ally of the United States. His reflections on President Kennedy have been evaluated as the weakest part of this book. The press accused the longest-serving minister in the history of the Netherlands of insufficient efforts in the matter of New Guinea (Luns). In the long run, even Luns agreed with American diplomats, that the United States was right and helped the Netherlands 
'to get out' (Biesheuvel). For the Netherlands it was another stage on the way to accepting its status as mainly a European state. The Kingdom of the Netherlands consisted of six islands of the Netherlands Antilles and Suriname, which in 1975 gained independence from the Netherlands. The loss of most estates and the loosening of ties with the rest of the kingdom has directed the Netherlands even more towards European affairs.

The purpose of this paper was to demonstrate how the Dutch East Indies/Indonesia became an important part of U.S. foreign policy. One conclusion to be drawn is that even though several factors influenced official the American position toward Indonesia, its potential role in the policy of containment was crucial. The Netherlands was regarded as a close and loyal ally, yet U.S. global policy required sacrifices. The Netherlands, however, was not stubborn on decolonization matters, yet it wished to be able to conduct this process gradually. Moreover, the Dutch were part of the Atlantic community, and strongly opposed communism and its rise throughout the world, they would thus not accept it in Indonesia and would not oppose Indonesian cooperation with the United States, also economically. For years, the American side was blamed for abandoning its ally. To a large extent, however, again, after many years, this difficult moment in Dutch-American relations is justified by the fact that the necessity to withdraw from Indonesia and New Guinea was unavoidable, and additionally there was a danger of a conflict resembling the Vietnam War. According to Dutch historian, the United States being chosen as the representative of the Committee of Good Offices and the United Nation Commission for Indonesia was good for the latter, and for the Netherlands as well (Berkel, and Goei 203). Despite their bitter feelings, Dutch politicians have always understood that to criticize the United States is to weaken the Atlantic community, which is against the interests of the Netherlands. Over the years, it appears as obvious that the Netherlands had no possibility to maintain its colonial empire. In politics, however, even a superpower could have doubts. President Dwight Eisenhower, frustrated by Indonesian politics in 1954, asked his National Security Council: 'Why the hell did we ever urge the Dutch to get out of Indonesia?' (qtd. in Frey 609).

\section{References}

"Excerpts from Sukarno's Address Before Assembly Calling for Transfer of U.N." The New York Times 30 September 1960.

Balicki, Jan, and Maria Bogucka. Historia Holandii. Wrocław: Zakład Narodowy im. Ossolińskich, 1989.

Berkel, Klaas van, and Leonie de Goei (eds). The International Relevance of Dutch History. The Hague: Royal Netherlands Historical Society 2010, https://doi.org/10.18352/ bmgn-lchr.7113.

Biesheuvel, Barend. Department of State Memorandum of Conversation, April 24, 1968, Foreign Minister Luns. Department of State subject-numerical files 1967-1973, reel 2 (microfilm edition, Roosevelt Study Center, Middelburg).

Brinkley, Alan. American History: A Survey. Boston: McGraw-Hill College, 1999.

Chaiklin, Martha. "Monopolists to Middlemen: Dutch Liberalism and American Imperialism in the Opening of Japan." Journal of World History. Vol. 21, No. 2, 2010: 249-69, https:/ / doi. org/10.1353/jwh.0.0131. 
Frey, Marc. "Decolonization and Dutch-American Relations." Four Centuries of Dutch-American Relations 1609-2009 edited by Hans Krabbendam, Cornelis A. van Minnen and Giles Scott-Smith, Amsterdam: Boom, 2009: 609-21.

Gouda, Frances. "American Diplomatic Perspectives on the Dutch East Indies." Four Centuries of Dutch-American Relations 1609-2009, edited by Hans Krabbendam, Cornelis A. van Minnen and Giles Scott-Smith, Amsterdam: Boom, 2009: 520-30.

Gouda, Frances, and Thijs Brocades Zaalberg. American Visions of the Netherlands East Indies/ Indonesia. Amsterdam: Amsterdam University Press 2002, https://doi.org/10.1515/ 9789048505036.

Hellema, Duco. "The Politics of Asymmetry: The Netherlands and the United States since 1945." Four Centuries of Dutch-American Relations 1609-2009, edited by Hans Krabbendam, Cornelis A. van Minnen and Giles Scott-Smith, Amsterdam: Boom, 2009: 579-97.

Herman B. Baruch American Embassy to the Secretary of State, The Hague August 13, 1948, Department of State Decimal File, 1945-1959 (microfilm edition, Roosevelt Study Center, Middelburg).

Hooker, Mark T. The History of Holland. Westport: Greenwood Press, 1999.

Jackson, Robert, and Georg Sørensen. Wprowadzenie do stosunków międzynarodowych. Teorie i kierunki badawcze, translated by Aleksandra Czwojdrak. Kraków: Wydawnictwo Uniwersytetu Jagiellońskiego, 2012.

Kalb, B. “Sukarno Affirms Soviet Friendship." New York Times 25 February 1960.

Luns, December 2, 1968, de Jong-Luns visit to USA 1969. Department of State subject-numerical files 1967-1973, reel 2 (microfilm edition, Roosevelt Study Center, Middelburg).

Luns, December 7, 1967, de Jong cabinet 1967-1969. Department of State subject-numerical files 1967-1973, reel 4 (microfilm edition, Roosevelt Study Center, Middelburg).

Marsh, David, and Gerry Stoker. Teorie i metody w naukach politycznych, translated by Joanna Tegnerowicz. Kraków: Wydawnictwo Uniwersytetu Jagiellońskiego, 2006.

Megens, Ine. American Aid to NATO Allies in the 1950s: the Dutch Case. Amsterdam: Thesis Publisher, 1994.

Memorandum of Conversation between minister van Boetzekaer and Ambassador Baruch, December 31, 1947, Department of State Decimal File, 1945-1959 (microfilm edition, Roosevelt Study Center, Middelburg).

Modelski, George. Long Cycles in World Politics. London: The McMillan Press, 1987, https:/ / doi.org/10.1007/978-1-349-09151-5.

National Intelligence Survey, Netherlands, Section 52 Structure of the Government, June 1951, p. 22 (Roosevelt Study Center microfilm).

Pijpers, Alfred. "The Netherlands. The Weaning Pull of Atlanticism." The Actors in Europe Foreign Policy. edited by Christopher Hill, London: Routledge 1996.

Rochon, Thomas R. The Netherlands. Negotiating Sovereignty in an Interdependent World. Boulder: Westview Press, 1999.

Roholl, Marja. "Uncle Sam: An Example for All? The Dutch Orientation in the Social and Cultural Field, 1945-1969." Dutch-American Relations 1945-1969. A Partnership. Illusion and Facts, edited by Hans Loeber. Assen/Maastricht: Van Gorcum, 1992.

Simpson, Brad. "Power, Politics, and Primitivism: West Papua's Struggle for Self-Determination." Critical Asia Studies. Vol. 35, No. 3, 2003: 469-75, https://doi.org/10.1080/1467271 032000109944.

Staden, Alfred van. "American-Dutch Political Relations since 1945. What Has Changed and Why?". A Bilateral Bicenntennial. A History of Dutch-American Relations, 1782-1982, edited by J.W. Schulte Nordholt and Robert P. Swierenga, Amsterdam: Meulenhoff, 1982, https:/ / doi.org/10.18352/bmgn-lchr.2367.

Teitler, Gerke. "Sea Power on the Decline. Anti-Americanism and the Royal Netherlands Navy 1942-1952." European Contributions to American Studies. Vol. 11, 1997: 72-84. 
Telegram, George Kennan to George Marshall “Long Telegram”, February 22, 1946. Harry S. Truman Administration File, Elsey Papers, https://www.trumanlibrary.org/whistlestop/study_collections/coldwar/documents/pdf/6-6.pdf.

Touwen, Jeroen. "American Trade with the Netherlands and the Dutch East Indies." Four Centuries of Dutch-American Relations 1609-2009, edited by Hans Krabbendam, Cornelis A. van Minnen and Giles Scott-Smith, Amsterdam: Boom, 2009: 271-83.

Vandenbosch, Amry. Dutch Foreign Policy Since 1815. The Hague: Martinus Nijhoff, 1959, https:// doi.org/10.1007/978-94-011-6809-0.

Webster, David. "Regimes in Motion: The Kennedy Administration and Indonesia's New Frontier, 1960-1962." Diplomatic History. Vol. 33, No. 1, 2009: 95-123, https://doi. org/10.1111/j.1467-7709.2008.00748.x.

Wesseling, Henk L. Imperialism and Colonialism. Essays on the History of European Expansion. Westport: Greenwood Press, 1997. 